\title{
The criminal justice system's longstop: the work of the Criminal Cases Review Commission
}

\author{
by Graham Zellick
}

$\mathrm{O}$ nce the Court of Appeal, Criminal Division has dismissed an appeal against a conviction, or refused leave to appeal, it has no further jurisdiction. The Court itself cannot permit a further appeal. Nor can any other court cause a case to return to the Court of Appeal. And the power of the Home Secretary to refer convictions for a new appeal was abolished by the Criminal Appeal Act 1995.

What that Act did, however, was replace the Home Secretary's power by a new independent body, the Criminal Cases Review Commission, which alone can refer convictions and sentences back to the Court of Appeal or the Crown Court (in respect of magistrates' court decisions) and the corresponding courts in Northern Ireland. Once the Commission has referred a case, the court must hear it.

It was formerly open to the appellant to argue any grounds he chose, but a recent statutory provision just brought into effect will limit the appellant to those grounds on which the Commission has made the reference unless the court grants permission for other grounds to be added. The Commission itself has no role to play at this stage. Its work is complete once the conviction or sentence has been referred, unless the court asks us to do further work.

The Commission reviews around 900 convictions and sentences each year. The majority of applications are in respect of convictions in the Crown Court. There must normally have been an unsuccessful appeal or application for leave to appeal before the Commission can consider a reference unless there are exceptional circumstances. Likewise, a reference must normally be based on new evidence or argument unless there are exceptional circumstances to justify a departure from that requirement.

The Commission is an independent statutory body which receives its funding from the Home Office and is accountable to Parliament through the Home Secretary and the Home Affairs Committee before which it is periodically called to give evidence. The Commission is not subject to the Parliamentary Ombudsman, but is amenable to judicial review. In exercising its judicial review jurisdiction, the High Court has acknowledged that Parliament has entrusted this important responsibility to the Commission and it is not for the courts to substitute their view for that of the Commissioners unless we have strayed outside the legal limits.

The Act requires a minimum of 11 Commissioners, who are appointed by the Queen on the recommendation of the Prime Minister, one-third of whom must be lawyers and two-thirds of whom must have some familiarity with the criminal justice system. One Commissioner must have knowledge of criminal justice in Northern Ireland.

The Act does not stipulate how the Commission should discharge its duties, except that it does reserve certain decisions to committees of at least three Commissioners. Thus, it is only such a committee that can refer a case for appeal or appoint a police force to carry out inquiries on its behalf.

The vast majority of cases are, in fact, decided by a single Commissioner. The Commission has never delegated decision-making to its staff, who number around 100, about half of whom are caseworkers. As with the Commissioners, the caseworkers are not all lawyers. Most have casework experience in other organisations, such as trading standards or the police. The Commissioners themselves bring a range of skills and experience to bear on the search for miscarriages of justice: the lawyers are drawn from private practice in both civil and criminal law, the Crown Prosecution Service, the military and academia; the non-lawyers include a former local government chief executive, a former chief constable, a tax accountant, a consultant forensic psychiatrist and a chief executive from industry.

Cases are screened on arrival and, if it appears that the review can be completed within five case-working days (albeit over a longer period of time), then the case will be allocated for almost immediate review. Cases that will require more effort are placed in a queue and allocated in 
order unless prioritised for special reasons such as the health of the applicant or a crucial witness. These waiting times are longer than the Commission would like, but resources are limited.

Staff members carry out the review working in consultation with one or more Commissioners. The Commission has formidable powers available to it, notably the power to obtain any material, document or exhibit in the possession of any public body. There are no limits: it extends to PII material, ministerial papers, security service files, medical records and census returns, for example. Unfortunately, there is no corresponding power (as there is in Scotland) to obtain material from private persons or bodies. Nor does the reach of this provision extend to Scotland, which can cause complications. Another difficulty is caused by the fact that the Commission and its work are not recognised for the purposes of international mutual co-operation in criminal justice, owing to a statutory oversight, and this can occasion significant delays.

The Commission is empowered to take whatever steps are necessary to review a conviction or sentence. This may take the form of interviewing witnesses, seeking statements, commissioning expert reports and reexamining exhibits. The Commission operates in an inquisitorial fashion and does not normally hold oral hearings.

The words "miscarriage of justice" do not appear in the statute. The Commission is not explicitly charged with the task of ascertaining innocence of guilt. In fact, its role links to and derives from the approach of the Court of Appeal itself: is the conviction safe? The concept of safety is, of course, something that has been developed in the jurisprudence of the Court of Appeal over many years. The Commission plays a role in its continued development by referring cases which may afford the Court an opportunity to clarify or develop the law.

The test the Commission must apply is to assess whether there is a real possibility that the conviction (or sentence) will be overturned. Some 30 or 40 cases a year are found to satisfy that criterion and are referred, with around 70 per cent resulting in a successful appeal by the appellant. Real possibility lies somewhere between a bare possibility on the one hand and a racing certainty on the other, to use the words of Lord Bingham of Cornhill LCJ. It is not (as some have supposed) the same test as applied by the single judge or full court in deciding applications for leave to appeal.

Some argue that the Commission is too cautious and it applies the test incorrectly. That is certainly not the view of the judges. Our critics insist that the proportion of cases in which we find that there is no real possibility is far too high and on some intuitive basis they are convinced that miscarriages of justice are more common. The Commission, for its part, performs its task with no preconceptions or biases, but acts on what it finds in the course of a review, bearing in mind that there must normally be some evidence or argument not previously adduced before a case may be referred. It is not enough for the Commission merely to think that the jury or the Court of Appeal may have got it wrong.

Even if a real possibility is found, the Commission is under no duty to refer the case. It has a discretion whether to do so or not, although it is a discretion very sparingly exercised. In the overwhelming majority of cases, a real possibility of success in the Court of Appeal will make it right that the case should be heard, but there may be cases where there is no discernible public or private interest in making the reference. One such case was that of Timothy Evans, who was executed for murder in respect of which a free pardon was subsequently granted and compensation was paid to members of his family. The Commission could see no benefit in referring that conviction to the Court merely for the purpose of formally extinguishing the conviction (which admittedly a free pardon does not do). The Commission's decision was endorsed by the Divisional Court on judicial review.

Another function of the Commission is to carry out inquiries at the direction of the Court of Appeal whether on an appeal or on an application for leave to appeal. A number of such requests have been made. A role in relation to offering advice to the Home Secretary on the exercise of the royal prerogative of mercy has never been utilised.

It is true that the real-possibility-of-quashing test throws the Commission's spotlight on matters other than innocence or guilt. In a number of references, however, convictions have been shown to be unsafe in circumstances that leave little doubt that the wrong person was convicted. In other cases, that may not be so: the error, irregularity or new evidence may simply mean that the original trial and result are not sustainable. Along with the Court of Appeal, we therefore play a role in maintaining the integrity of the criminal process and ensuring that people do not remain convicted inappropriately.

Some of the cases we examine are very old. Indeed, in a few, they are not only old but the convicted person is no longer alive. It is only where there is a reasonably close surviving relative that the Court of Appeal has jurisdiction in such cases and that requirement imposes some limitation on the age of cases we are likely to consider, but close surviving relatives do have a real interest in these matters and it is right that they should not be excluded from the process.

With old cases, the question arises of what law should be applied: is it the law at the time of the trial and first appeal or the law of today? The basic answer, given by the courts, is that in the case of statute law, it is the law in force at the time, but in the case of the common law and standards of fairness, it is the law of today, though in respect of standards of fairness, the paramount question remains the safety of the conviction and not merely any departure from 
today's rules. Whether it is right that the contemporary law should be applied is an interesting question which deserves fuller consideration.

The Commission issues its decisions in the form of fullyreasoned statements of reasons which are made available to the applicant and, in the case of referrals, also to the court and the relevant prosecutor. Confidentiality provisions in the 1995 Act prevent general publication of the statements by the Commission.

It is sometimes suggested that a different test should be used, perhaps one that refers to a possible miscarriage of justice or even to innocence. Another suggestion is that the final decision should not be made by the relevant appeal court, but either by the Commission itself or some other specially-constituted body. Both of these arguments it seems to me are flawed.

While it would indeed be possible to confine our attention to something called miscarriages of justice, provided that term were defined, or even to innocence, it would give rise to a very unsatisfactory situation where our work disclosed grounds for concluding that a conviction was not safe and would not be upheld if it were to come again before the relevant appeal court but we could take no action. A miscarriage of justice or innocence test would greatly circumscribe our remit. If there are areas of law productive of references in unmeritorious cases - such perhaps as adverse inferences, provocation or diminished responsibility - it is likely that what is needed is reform of the law in question, whether by the Court of Appeal or Parliament, as appropriate, rather than a restriction of the Commission's power.

Removing the final decision from the Court of Appeal would be a serious mistake, since it would introduce a rival jurisdiction and would do nothing to lead to improvements, clarification or consistency in the law. Indeed, it would do the reverse and exacerbate the problems.

There is a good relationship between the judges and the Commission, each respecting the independence and defined role of the other. It is a tribute to the judiciary that it operates the machinery of referral so fairly, in the interests of justice, and we can all take some pride in a system that means that the door to justice is never closed, that justice is prized above finality. Our work, both in making references and refusing to do so, also contributes to public confidence in the administration of criminal justice.

\section{Professor Graham Zellick}

The author is Chairman of the Criminal Cases Review Commission. A former Vice-Chancellor and Emeritus Professor of Law of the University of London, he is an Honorary Professor in the School of Law of the University of Birmingham, a Master of the Bench of the Middle Temple, an Honorary Fellow of Gonville and Caius College, Cambridge, an Academician of the Academy for Social Sciences and an Honorary Fellow of the Society for Advanced Legal Studies. 